\title{
Tingkat Akurasi dalam Mengidentifikasi Penyakit Telinga Menggunakan Metode Forward Chaining dan Certainty Factor
}

\author{
M Ilham Aldyno ${ }^{1 凶}$, Sumijan $^{2}$, Yuhandri $^{3}$ \\ 1, 2, 3 Universitas Putra Indonesia "YPTK" Padang \\ aldynomilham25@gmail.com
}

\begin{abstract}
The ear is an important organ that functions to hear and maintain body balance because it is located close to the brain and nerves throughout the body. The ear is known to be sensitive and vulnerable considering the size of the ear and other supporting organs around it are small and the moisture factor that can trigger fungus. In some communities in maintaining ear health often underestimate this, therefore to help and facilitate the community made an expert system application. An expert system is a collection of knowledge and experience from an expert adopted into a computer so that it can solve problems like an expert. In this discussion the aim of the expert system is to measure the level of accuracy in identifying ear disease so that it becomes an initial reference when consulting a doctor. The method used is the forward chaining method and certainty factor. The results of this study use the Forward Chaining Method to arrange the rule and Certainty factor (CF) for weighting in calculating the accuracy of each symptom. Test data on 10 people gave an accuracy value $80 \%$ then processed by giving results. Based on the results obtained from the application of an expert system to measure the level of accuracy in identifying ear disease can provide a solution making it easier for users to consult telingga disease, so they can find out earlier in handling.
\end{abstract}

Keywords: Expert System, Identification, Ear Disease, Forward Chaining, Certainty Factor.

\begin{abstract}
Abstrak
Telinga merupakan organ yang berfungsi untuk mendengar dan menjaga keseimbangan tubuh karena letaknya yang berdekatan dengan otak dan saraf keseluruh tubuh. Telinga dikenal sensitif dan rentan mengingat ukuran telinga dan organ pendukung lain disekitarnya berukuran kecil serta faktor kelembaban yang dapat memicu jamur. Pada sebagian masyarakat dalam menjaga kesehatan telinga sering menyepelekan hal tersebut, oleh karena itu untuk membantu dan mempermudah masyarakat dibuat aplikasi sistem pakar. Sistem pakar merupakan kumpulan pengetahuan dan pengalaman dari seorang pakar yang diadopsi kedalam komputer sehingga dapat menyelesaikan permasalahan seperti seorang pakar. Pada pembahasan ini tujuan sistem pakar adalah mengukur tingkat akurasi dalam mengidentifikasi penyakit telinga sehingga menjadi referensi awal ketika berkonsultasi dengan dokter. Metode yang digunakan yaitu, metode Forward Chaining dan Certainty Factor. Hasil penelitian ini menggunakan Metode Forward Chaining untuk menata rule dan Certainty Factor (CF) untuk pembobotan dalam perhitungan akurasi dari masing-masing gejala. Data uji terhadap 10 orang memberikan nilai akurasi $80 \%$ kemudian diolah dengan memberikan hasil. Berdasarkan hasil yang diperoleh dari aplikasi sistem pakar untuk mengukur tingkat akurasi dalam mengidentifikasi penyakit telinga dapat memberikan solusi sehingga memudahkan user untuk melakukan konsultasi penyakit telingga, sehingga dapat mengetahui lebih dini dalam penanganannya.
\end{abstract}

Kata kunci: Sistem Pakar, Identifikasi, Penyakit Telinga, Forward Chaining, Certainty Factor.

\section{Pendahuluan}

Perkembangan teknologi saat ini begitu pesat, mendapatkan informasi juga lebih cepat serta banyak pengaruh dari teknologi yang dapat dirasakan. Dibalik perkembangan teknologi tersebut, komputer menjadi salah satu faktor penunjang perkembangan teknolgi Sistem Pakar memberikan kemudahan terhadap tersebut karena dapat mengolah data lebih cepat. Salah problem solving di bidang medis sepeti THT[7]. Pada satu cabang komputer yaitu Artificial Intelligence [1] sebuah kasus Hearing Loss yang merupakan suatu [2]. Pada salah satu sub divisinya, yaitu Sistem pakar keadaan dimana seseorang tidak dapat mendengar pada [3][4][5]. Sistem Pakar merupakan program komputer lingkungan sekitarnya, kemungkinan hal tersebut yang memiliki pengetahuan dan pengalaman dari terjadi karena Telinga tersumbat atau ada bakteri yang seorang pakar untuk menyelesaikan masalah seperti muncul di wilayah telinga[8]. Menurut WHO juga, ada seorang pakar. Sumber pemrosesan atau otak dari sekitar 466 juta orang yang hidup dengan mengalami Sistem pakar adalah Inference Engine (Mesin Inferensi) lumpuh pada pendengaran termasuk sekitar 34 juta yang juga dikenal sebagai Rule Interpreter (Penerjemah anak-anak[9]. Pada anak-anak umur 12 tahun, salah 
satu jenis penyakit telinga yang bernama Otitis Media dengan Efusi (OME) menjadi penyebab umum berkurangnya kualitas pendengaran [10]. Pasien yang lahir dengan bibir sumbing juga memiliki resiko tinggi kehilangan pendengaran akibat Otitis Media dengan Efusi, faktor utama yang menyebabkan efusi telinga tengah adalah disfungsi terhadap Tuba Eustachius [11]. Berdasarkan hal tersebut peneliti mencoba membuat Aplikasi Sistem Pakar dalam mengidentifikasi penyakit telinga untuk mempermudah masyarakat untuk mengetahui kemungkinan penyakit telinga yang diderita

Metode yang digunakan pada penelitian ini adalah metode Forward Chaining dan Certainty Factor. Metode Forward Chaining merupakan bagian dari Sistem Pakar [12]. Metode Forward Chaining menggunakan teknik inferensi yang dimulai premis yang berisikan fakta pengetahuan [13][14]. Fakta akan dicocokkan sehingga menghasilkan kesimpulan akhir [15]. Metode Certainty Factor digunakan untuk mengakomodasi ungkapan meragukan yang sering terjadi saat pakar menganalisa informasi [16][17][18][19]. Certainty factor nantinya akan memberikan nilai kepastian terhadap fakta dan aturan sehingga dapat memberikan keputusan pada sistem pakar diagnosa penyakit [20][21][22].

Penelitian terdahulu oleh [23] mengenai Sistem Pakar diagnosa penyakit menular menggunakan metode Forward Chaining dan Certainty Factor. Berdasarkan pengujian sistem yang telah dilakukan kepada 20 orang ujicoba dan dibandingkan dengan pendapat Dokter, maka didapatkan hasil presentase keakuratan sebesar $85 \%$. Penelitian terdahulu terhadap penyakit dengan metode yang sama juga dilakukan oleh [24] terhadap penyakit Pertusis pada anak dengan melalui pengujian sistem mendapatkan hasil $97 \%$. Penelitian terdahulu selanjutnya oleh [25] dalam Penerapan metode Forward Chaining dan Certainty Factor pada Sistem Pakar diagnosa Hama Anggrek Coelogyne Pandurata melalui pengujian sistem memperoleh hasil $93 \%$. Penelitian terdahulu lainnya juga dilakukan oleh [26] dalam menentukan alat kontrasepsi, dimana akurasi sistem yang didapatkan sebesar $75 \%$.

Untuk mencegah dampak dari penyakit telinga, diharapkan masyarakt dapat menjaga kesehatan telinga dan mendeteksi dini penyakit telinga guna mencegah permasalahan yang lebih serius dalam efektifitas sehari-hari [27].

\section{Metodologi Penelitian}

Metode penelitian merupakan tahap-tahap dalam melakukan penelitian yang disusun berdasarkan kerangka kerja agar lebih terstruktur kemudian diuraikan masing-masing tahapannya.

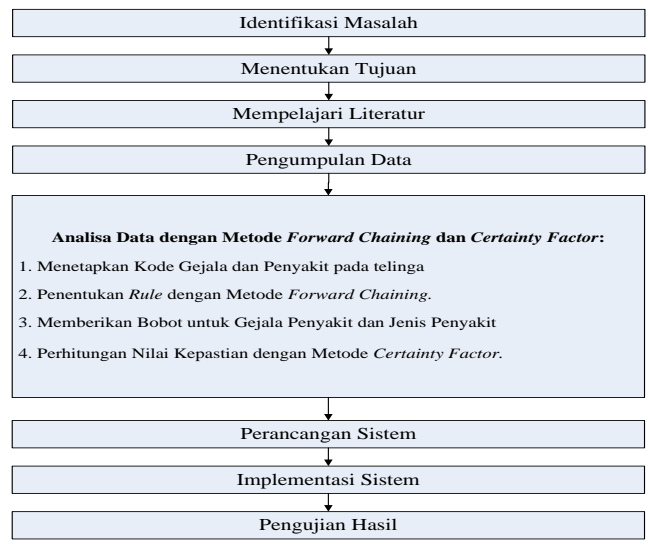

Gambar 1. Kerangka Kerja Penelitian

Berdasarkan kerangka kerja penelitian, maka kerangka kerja penelitian diuraikan sebagai berikut:

1. Identifikasi masalah

Identifikasi masalah merupakan tahap untuk menemukan permasalahan sebelum dilakukan penelitian. Dengan mencari tahu permasalahan pada objek untuk mencari alternatif serta solusi yang berkaitan dengan permasalahan. Maka tahap dalam mengidentifikasi masalah dapat memperoleh uraianuraian secara lengkap mengenai masalah dan langkah yang tepat dalam menyelesaikan pemecahan masalah.

2. Menentukan Tujuan

Menentukan tujuan merupakan hal penting dalam penelitian, dimana dengan memiliki tujuan maka penyelesaian dapat terarah. Pada penelitian ini tujuannya adalah menentukan tingkat akurasi dalam mengidentifikasi penyakit telinga

\section{Mempelajari Literatur}

Mempelajari literatur merupakan tahap dalam melakukan pembelajaran mengenai penerapan sistem pakar serta penerapan metode Forward Chaining dan Certainty Factor sebagai metode yang digunakan pada penelitian. Literatur tersebut nantinya digunakan sebagai referensi untuk mendiagnosis penyakit dan mempelajari teori tentang jenis dan gejala penyakit pada telinga [31] yang nantinya mendapatkan hasil jenis penyakit yang diderita dan cara pengobatan atau solusi. Teknik pembelajaran ini didapatkan dari berbagai jurnal dan buku yang memiliki kaitan dengan konsep sistem pakar [32], metode Forward Chaining dan Certainty Factor, serta teori-teori penyakit telinga.

\section{Mengumpulkan Data}

Data juga merupakan hal penting, apabila tidak ada data maka tidak ada yang diolah. Dalam mengumpulkan data, peneliti mendapatkan data yang merupakan sumber dari pakar atau dokter ahli. Untuk data penunjang pada penelitian ini didapatkan dari jurnal, buku, dan referensi lain. Penelitian ini juga dilakukan dengan melakukan wawancara pada dokter ahli di tempat penelitian, yaitu RS Naili DBS, Kota Padang. 


\section{Analisa Data dari Metode Forward Chaining dan Certainty Factor}

Pada tahap ini dilakukan proses analisa data yang sesuai dengan kebutuhan dari metode yang digunakan. Untuk tahapan Analisa data berdasarkan kebutuhan dari metode forward chaining dan certainty factor ini adalah:

a. Menetapkan data penyakit sebagai basis 3.1.1 Data pengetahuan.

b. Penentukan rule dengan metode Forward Data yang diolah merupakan data mengenai penyakit Chaining.

Telinga yang didapatkan dari wawancara dengan dokter

c. Memberikan Bobot untuk Gejala Penyakit dan Poli THT, RS Naili DBS. Data terdiri dari 10 jenis Jenis Penyakit.

d. Perhitungan nilai kepastian dengan metode Fertainty Factor.

\section{Perancangan Sistem}

Pada tahap ini akan dilakukan rancangan terhadap sistem dengan perhitungan terhadap nilai kepastian dari seorang user dalam diagnosis penyakit telinga berdasarkan rule yang sudah dibentuk.

\section{Implementasi Sistem}

Data yang ada pada tahap ini diolah dan fakta atau kondisi (rule) yang sudah didapatkan akan diproses dengan aplikasi yang telah dirancang, sehingga dihasilkan berupa sebuah pengetahuan informasi mengenai penyakit dan presentase hasil kepastiannya

\section{Hasil dan Pembahasan}

Pada tahap ini, peneliti melakukan simulasi setelah mendapatkan data dan pembuatan sistem pakar guan mengetahui apakah sistem yang dirancang sesuai dengan tujuan yang diharapkan. Dalah tahapan ini ada beberapa mekanisme pengujian yaitu:

a. Mengelompokkan jenis dan gejala penyakit telinga sehingga menjadi sebuah tabel yang berisikan rincian dari data.

b. Membuat rule atau aturan berdasarkan gejala penyakit.

c. Hasil dari rule tersebut kemudian menghasilkan suatu diagnosis jenis penyakit telinga yang dilihat berdasarkan gejala yang dirasakan pasien.

d. Menguji kesesuaian dan diagnosis jenis penyakit telinga. Pengujian dilakukan dengan mengambil sampel data dari RS Naili DBS

\section{Hasil dan Pembahasan}

\subsection{Analisa dan Perancangan}

Tahap analisa dan perancangan merupakan tahap pembahasan yang diawali oleh Analisa Sistem kemudian Perancangan terhadap Sistem. Tahapan Analisa Sistem bertujuan untuk mendapatkan pengetahuan yang berkaitan dengan tingkat akurasi dalam mengidentifikasi penyakit telinga dengan menggunakan dua buah metode yaitu metode Forward Chaining dan Certainty Factor. penyakit, 14 gejala klinis, dan penatalaksaan maupun solusi dari penyakit yang berkaitan. Data akan diproses guna untuk menghasilkan tingkat akurasi dalam mengidentifikasi penyakit telinga. Pemrosesan tersebut menggunakan gabungan dua buah metode yaitu metode Forward Chaining dan Certainty Factor.

\subsubsection{Analisa Sistem}

Sebagaimana yang telah digambarkan pada bagan alur analisa dan perancangan, maka dalam menganalisa dan merancang Aplikasi Sistem Pakar untuk mengukur tingkat akurasi dalam mengidentifikasi penyakit telinga digunakan dua buah metode yaitu metode Forward Chaining dan Certainty Factor yang digambarkan pada Gambar 3 sebagai berikut:

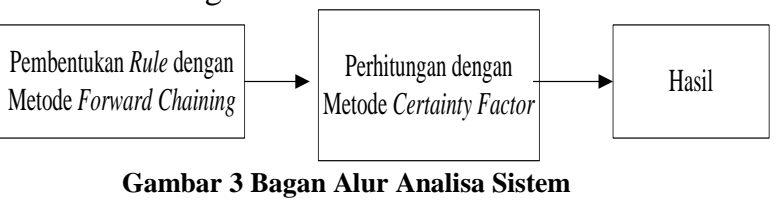

\section{Pembentukan Rule dengan menggunakan metode Forward Chaining}

Teknik Inferensi diawali dengan pencarian dengan mencocokkan aturan dalam basis pengetahuan, sehingga dapat menunjang keberhasilan dalam mengukur tingkat akurasi dalam mengidentifikasi penyakit telinga. Teknik Inferensi yang dipakai adalah metode Forward Chaining, yang mana metode ini digunakan untuk mengidentifikasi penyakit telinga berdasarkan gejala yang ada. Berikut algoritma langkah-langkah metode Forward Chaining:

Tahapan proses Forward Chaining:
a. Mendefinisikan Masalah
b. Menyiapkan Data
c. Menentukan Rule Berdasarkan Data yang Sudah Ada
d. Hasil Identifikasi Rule

a. Mendefinisikan Masalah

Kebiasaan masyarakat yang menghiraukan atau menyepelekan penyakit telinga menjadi masalah, sehingga peneliti melakukan penelitian yang bertujuan untuk membuat Aplikasi Sistem Pakar guna mengukur tingkat akurasi dalam mengidentifikasi penyakit telinga. Aplikasi Sistem Pakar tersebut diharapkan 
dapat mempermudah masyarakat menyampaikan keluhan pada saat konsultasi dengan dokter sehingga memberikan solusi atau penata laksanaan untuk mengatasi penyakit yang diderita tersebut.

b. Menyiapakan Data

Data yang disiapkan dalam metode Forward Chaining adalah data penyakit telinga dan gejala klinis yang dirasakan oleh pasien. Data kemudian akan diolah untuk pembentukan aturan atau rule.

1. Data Jenis Penyakit Telinga

Adapun data jenis penyakit telinga dapat dilihat pada Tabel 1 sebagai berikut:

Tabel 1 Data Jenis Penyakit Telinga

\begin{tabular}{|c|l|l|}
\hline No. & Kode & \multicolumn{1}{|c|}{ Penyakit } \\
\hline 1. & JP01 & Otitis Externa Sirkumskripta \\
\hline 2. & JP02 & Otitis Externa Difusa \\
\hline 3. & JP03 & Otitis Externa Maligna \\
\hline 4. & JP04 & Otitis Media Efusi \\
\hline 5. & JP05 & Otitis Media Akut \\
\hline 6. & JP06 & Otitis Media Supuratif Kronik \\
\hline 7. & JP07 & Otosklerosis \\
\hline 8. & JP08 & Meniere $\square$ \\
\hline 9. & JP09 & Tuli mendadak atau Sudden deafness \\
\hline 10. & JP10 & $\begin{array}{l}\text { Benign Paroxysmal Positional Vertigo } \\
\text { (BPPV) }\end{array}$ \\
\hline
\end{tabular}

2. Data Gejala Penyakit Telinga

Adapun Data gejala penyakit telinga dapat dilihat pada Tabel 2 sebagai berikut:

\begin{tabular}{|c|l|l|}
\multicolumn{3}{|c|}{ Tabel 2 Data Gejala Penyakit Telinga } \\
\hline No. & \multicolumn{1}{|c|}{ Kode } & \multicolumn{1}{c|}{ Gejala } \\
\hline 1. & KGP01 & Rasa nyeri \\
\hline 2. & KGP02 & Rasa penuh atau telinga tersumbat \\
\hline 3. & KGP03 & Telinga berbau tidak sedap \\
\hline 4. & KGP04 & Kualitas pendengaran berkurang \\
\hline 5. & KGP05 & Keluar cairan dari telinga \\
\hline 6. & KGP06 & Rasa gatal pada telinga \\
\hline 7. & KGP07 & Tinnitus (Telinga berdengung) \\
\hline 8. & KGP08 & $\begin{array}{l}\text { Vertigo (Sensasi berputar didalam atau diluar } \\
\text { kepala yang tiba-tiba) }\end{array}$ \\
\hline 9. & KGP09 & Batuk Pilek \\
\hline 10. & KGP10 & Demam \\
\hline 11. & KGP11 & Mual/ Muntah \\
\hline 12. & KGP12 & $\begin{array}{l}\text { Autofoni (Pendengaran yang sangat keras } \\
\text { dari suara sendiri) }\end{array}$ \\
\hline 13. & KGP13 & Tuli (Tidak dapat mendengar) \\
\hline 14. & KGP14 & $\begin{array}{l}\text { Paracusis Willisi (Pendengaran yang lebih } \\
\text { baik saat berada dilingkungan bising) }\end{array}$ \\
\hline
\end{tabular}

c. Menentukan Rule Berdasarkan Data Yang Sudah Ada

Adapun hasil Pembentukan rule dapat dilihat pada Tabel 3 sebagai berikut:

\begin{tabular}{|c|c|}
\hline $\begin{array}{c}\text { Rule } \\
\text { ke }\end{array}$ & \multicolumn{1}{c|}{ Rule } \\
\hline 1. & $\begin{array}{l}\text { TF Nyeri AND Rasa penuh atau rasa telinga tersumbat } \\
\text { AND Keluar cairan dari telinga THEN Otitis Externa } \\
\text { Sirkumskripta }\end{array}$ \\
\hline \begin{tabular}{|} 
Tabel 3 Pembentukan Rule (Lanjutan) \\
ke
\end{tabular} & \multicolumn{1}{|c|}{ Rule } \\
\hline 2. & $\begin{array}{l}\text { IF Nyeri } A N D \text { Telinga berbau tidak sedap AND Gatal } \\
\text { THEN Otitis Externa Difusa }\end{array}$ \\
\hline 3. & $\begin{array}{l}\text { IF Nyeri } A N D \text { Keluar cairan dari telinga AND Gatal } \\
\text { THEN Otitis Externa Maligna }\end{array}$ \\
\hline
\end{tabular}

\begin{tabular}{|c|l|}
\hline 4. & $\begin{array}{l}\text { IF Nyeri AND Rasa penuh atau rasa telinga tersumbat } \\
\text { AND Kualitas pendengaran berkurang AND Tinnitus } \\
\text { THEN OME }\end{array}$ \\
\hline 5. & $\begin{array}{l}\text { IF Nyeri AND Rasa penuh atau rasa telinga tersumbat } \\
\text { AND Kualitas pendengaran berkurang AND Tinnitus } \\
\text { AND Demam THEN Otitis Media Akut }\end{array}$ \\
\hline 6. & $\begin{array}{l}\text { IF Telinga berbau tidak sedap AND Kualitas pendengaran } \\
\text { berkurang AND Keluar cairan dari telinga THEN Otitis } \\
\text { Media Supuratif Kronik }\end{array}$ \\
\hline 7. & $\begin{array}{l}\text { IF Kualitas pendengaran berkurang AND Tinnitus } A N D \\
\text { Vertigo AND Paracusis Willisi THEN Otosklerosis }\end{array}$ \\
\hline 8. & $\begin{array}{l}\text { IF Rasa penuh atau telinga tersumbat } A N D \text { Tinnitus } A N D \\
\text { Vertigo AND Muntah atau mual THEN Meniere }\end{array}$ \\
\hline 9. & $\begin{array}{l}\text { IF Kualitas pendengaran berkurang AND Tinnitus } A N D \\
\text { Vertigo THEN Tuli mendadak atau Sudden deafness }\end{array}$ \\
\hline 10 & IF Vertigo $A N D$ Muntah atau mual THEN BPPV \\
\hline
\end{tabular}

d. Hasil Identifikasi Rule

Identifikasi rule merupakan pembentukan rule yang dikonversikan menggunakan kode.

\begin{tabular}{|c|c|}
\hline $\begin{array}{c}\text { Rule } \\
\text { ke }\end{array}$ & $R$ \\
\hline 1. & $\begin{array}{l}\text { IF [KGP01] AND [KGP02] AND [KGP05] THEN } \\
\text { JP01 }\end{array}$ \\
\hline 2. & $\begin{array}{l}\text { IF [KGP01] AND [KGP03] AND [KGP06] THEN } \\
J P 02\end{array}$ \\
\hline 3. & $\begin{array}{l}\text { IF [KGP01] AND [KGP05] AND [KGP06] THEN } \\
\text { JP03 }\end{array}$ \\
\hline 4. & $\begin{array}{l}\text { IF [KGP01] AND [KGP02] AND [KGP04] AND } \\
\text { [KGP07]THEN JP04 }\end{array}$ \\
\hline 5. & $\begin{array}{l}\text { IF [KGP01] AND [KGP02] AND [KGP04] AND } \\
\text { [KGP07] AND [KGP10] THEN JP05 }\end{array}$ \\
\hline 6. & $\begin{array}{l}\text { IF [KGP03] AND [KGP04] AND [KGPO5] THEN } \\
\text { JP06 }\end{array}$ \\
\hline 7. & $\begin{array}{l}\text { IF [KGP04] AND [KGP07] AND [KGP08] AND } \\
\text { [KGP14] THEN JP07 }\end{array}$ \\
\hline 8. & $\begin{array}{l}\text { IF [KGP02] AND [KGP07] AND [KGP08] AND } \\
\text { [KGP11] THEN JP08 }\end{array}$ \\
\hline & $\begin{array}{l}\text { IF [KGP04] AND [KGP07] AND [KGP08] THEN } \\
\text { JP09 }\end{array}$ \\
\hline & IF [KGP08] AND [KGP11] THEN JP10 \\
\hline \multirow{2}{*}{\multicolumn{2}{|c|}{$\begin{array}{l}\text { Tabel } 4 \text { merupakan hasil akhir daari penelusuran } \\
\text { metode Forward Chaining. } \\
\text { 2. Perhitungan dengan metode } \text { Certainty Factor } \\
\text { Metode Certainty Factor (Faktor Kepastian) } \\
\text { merupakan metode yang digunakan untuk } \\
\text { membuktikan suatu fakta itu benar atau tidak dalam } \\
\text { bentuk metric yang biasanya digunakan dalam } \\
\text { pengaplikasian Sistem Pakar. Adapun algoritma } \\
\text { langkah-langkah dari metode Certainty Factor adalah } \\
\text { sebagai berikut: }\end{array}$}} \\
\hline & \\
\hline \multicolumn{2}{|c|}{$\begin{array}{l}\text { Tahapan proses Certainty Factor: } \\
\text { 1. Data } \\
\text { 2. Pemberian Bobot Nilai Certainty Factor Pakar dan User } \\
\text { 3. Perhitungan Certainty Factor } \\
\text { 4. Hasil Perhitungan }\end{array}$} \\
\hline
\end{tabular}

\section{Data}

Adapun data yang digunakan adalah hasil identifikasi rule yang merupakan point ke-4 dari algoritma langkah-langkah dengan metode Forward Chaining

2. Pemberian Bobot Nilai Certainty Factor Pakar dan 
User.

Bobot nilai Certainty Factor (CF) masing-masing diberikan dari Pakar dan User. Adapun pemberian bobot nilai $\mathrm{CF}$ oleh Pakar dapat dilihat pada Tabel 5 sebagai berikut:

\begin{tabular}{|c|c|c|c|}
\hline No. & $\begin{array}{c}\text { Kode } \\
\text { Gejala }\end{array}$ & Gejala & $\begin{array}{c}\text { CF } \\
\text { Pakar }\end{array}$ \\
\hline \multirow[t]{3}{*}{1.} & KGP01 & Nyeri & 0,8 \\
\hline & KGP02 & $\begin{array}{l}\text { Rasa penuh atau telinga } \\
\text { tersumbat }\end{array}$ & 0,8 \\
\hline & KGP05 & Keluar Cairan dari Telinga & 0,4 \\
\hline \multirow[t]{3}{*}{2.} & KGP01 & Nyeri & 0,4 \\
\hline & KGP03 & Telinga berbau tidak sedap & 0,6 \\
\hline & KGP06 & Gatal & 0,8 \\
\hline \multirow[t]{3}{*}{3.} & KGP01 & Nyeri & 0,6 \\
\hline & KGP05 & Keluar cairan dari telinga & 0,6 \\
\hline & KGP06 & Gatal & 0,6 \\
\hline \multirow[t]{4}{*}{4.} & KGP01 & Nyeri & 0,8 \\
\hline & KGP02 & $\begin{array}{l}\text { Rasa penuh atau telinga } \\
\text { tersumbat }\end{array}$ & 0,8 \\
\hline & KGP04 & $\begin{array}{ll}\text { Kualitas } & \text { Pendengaran } \\
\text { Berkurang } & \\
\end{array}$ & 0,8 \\
\hline & KGP07 & Tinnitus & 0,4 \\
\hline \multirow[t]{5}{*}{5.} & KGP01 & Nyeri & 0,8 \\
\hline & KGP02 & $\begin{array}{l}\text { Rasa penuh atau telinga } \\
\text { tersumbat }\end{array}$ & 0,8 \\
\hline & KGP04 & $\begin{array}{ll}\begin{array}{l}\text { Kualitas } \\
\text { berkurang }\end{array} & \text { pendengaran } \\
\end{array}$ & 0,6 \\
\hline & KGP07 & Tinnitus & 0,4 \\
\hline & KGP10 & Demam & 0,4 \\
\hline \multirow[t]{3}{*}{6.} & KGP03 & Telinga berbau tidak sedap & 0,6 \\
\hline & KGP04 & $\begin{array}{ll}\text { Kualitas } & \text { pendengaran } \\
\text { berkurang }\end{array}$ & 0,8 \\
\hline & KGP05 & Keluar cairan dari telinga & 0,6 \\
\hline \multirow[t]{4}{*}{7.} & KGP04 & pendengaran & 0,6 \\
\hline & KGP07 & Tinnitus & 0,6 \\
\hline & KGP08 & Vertigo & 0,4 \\
\hline & KGP14 & Paracusis Willisi & 0,4 \\
\hline \multirow[t]{4}{*}{8.} & KGP02 & $\begin{array}{lll}\text { Rasa penuh atau telinga } \\
\text { tersumbat }\end{array}$ & 0,4 \\
\hline & KGP07 & Tinnitus & 0,4 \\
\hline & KGP08 & Vertigo & 0,8 \\
\hline & KGP11 & Muntah atau Mual & 0,4 \\
\hline \multirow[t]{3}{*}{9.} & KGP04 & $\begin{array}{ll}\begin{array}{l}\text { Kualitas } \\
\text { berkurang }\end{array} & \text { pendengaran } \\
\end{array}$ & 0,6 \\
\hline & KGP07 & Tinnitus & 0,6 \\
\hline & KGP08 & Vertigo & 0,4 \\
\hline \multirow[t]{2}{*}{10.} & KGP07 & Tinnitus & 0,8 \\
\hline & KGP11 & Muntah atau Mual & 0,6 \\
\hline
\end{tabular}

\begin{tabular}{|c|c|c|c|c|c|c|c|c|c|c|c|c|}
\hline \multirow[t]{2}{*}{$\mathrm{Mo}$} & \multirow{2}{*}{$\begin{array}{l}\text { Eodt } \\
\text { Gtjels }\end{array}$} & \multirow[t]{2}{*}{ Gejah } & \multicolumn{10}{|c|}{ Xiki CF } \\
\hline & & & & 2 & 3 & 4 & $\begin{array}{c}\text { PS } \\
5\end{array}$ & $\begin{array}{c}\text { PS } \\
6\end{array}$ & $\begin{array}{l}\text { PS } \\
?\end{array}$ & $\begin{array}{c}5 \\
8\end{array}$ & $\begin{array}{c}\text { PS } \\
\text { y }\end{array}$ & $\begin{array}{l}\mathrm{PS} \\
10\end{array}$ \\
\hline 1. & $\mathrm{ECP} 1$ & Timi & & 0,4 & a & 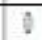 & 0.6 & 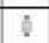 & 6 & 0 & 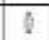 & 6 \\
\hline 1 & EGP2 & $\begin{array}{l}\text { Rase parth atsi } \\
\text { teligg tersubat }\end{array}$ & 4 & 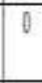 & 0 & $\theta$ & 86 & 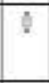 & 8 & 0 & $v$ & 7 \\
\hline 3 & ECPS & $\begin{array}{l}\text { Taling bethen tider } \\
\text { solby }\end{array}$ & 0 & 0 & 0,7 & 0,4 & 0 & 0 & 8 & 0 & 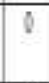 & 0,4 \\
\hline t. & BGP: & $\begin{array}{l}\text { Kulitas padenyzaI } \\
\text { behrurg }\end{array}$ & 0 & 0 & 0,6 & 0,4 & 4,4 & 1 & 1 & 1 & 06 & 02 \\
\hline 3 & EGP & $\begin{array}{l}\text { Kéter cains ton } \\
\text { thingr }\end{array}$ & 0 & 0 & 6.6 & 0,6 & $\theta$ & 0 & 8 & 1,4 & 0,6 & 1 \\
\hline 3 & EGP6 & Gatil & 0 & 0,8 & $\sqrt{2}$ & 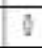 & $\theta$ & 0 & 1 & $\theta$ & 8 & 8 \\
\hline 1). & ECN? & Inmin & & 0 & 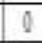 & 0 & 0,4 & 06 & 0 & 0 & 0 & 8 \\
\hline 3 & EGN18 & Yetigo & 0 & 0 & 0 & 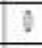 & 0 & 0 & 1 & 0 & 8 & 6 \\
\hline 7 & EGPV & Batik pile? & 0 & 0 & 0 & $\theta$ & $\theta$ & 0 & 1 & 0 & 8 & 8 \\
\hline 10 & ECPIO & Denem & 0,0 & 0 & 0 & 0 & 0 & 0 & 0 & 0 & 8 & 0 \\
\hline 11 & EGPI1 & Nhal abs! & 0 & 0 & 0 & 0 & 0 & 0 & 0.6 & 0 & 4 & 6 \\
\hline 12 & EGPN2 & Ansofori & 0 & 0 & 0 & $\theta$ & 0 & 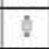 & 1 & 0 & 3 & is \\
\hline 13 & EGP13 & $\begin{array}{l}\text { Tul (Tduk taget } \\
\text { neadagny) }\end{array}$ & 0 & 0 & 0 & 0 & 0 & 0 & 0 & 0 & 8 & 0 \\
\hline 14 & KG:14 & Percosis Willi & 0 & 0 & 0 & $v$ & 0 & 1 & 0 & 0 & $\theta$ & 8 \\
\hline
\end{tabular}

\section{Perhitungan Certainty Factor}

Dalam perhitungan Certainty Factor, bobot nilai yang diberikan user akan dikalikan dengan bobot nilai yang diberikan oleh Pakar terlebih dahulu, dan diteruskan ke langkah perhitungan selanjutnya yaitu kombinasi. Proses perhitungan akan melibatkan masing-masing rule pada Tabel 4.6, dan terakhir yaitu dengan perhitungan persentase. Contoh proses perhitungan untuk memperoleh nilai $\mathrm{CF}$ akan dilakukan pada Pasien1 pada pembahasan berikut:

Perhitungan pertama yaitu Pasien 1 dengan rule 1:

Rule 1= IF [KGP01] AND [KGP02] AND [KGP05] THEN JP01

$$
\begin{aligned}
\mathrm{CFg} 1 & =\text { CFpasien } * \text { CFpakar } \\
& =0,8 * 0,8 \\
& =0,64 \\
\mathrm{CFg} 2 & =\text { CFpasien } * \text { CFpakar } \\
& =0,4 * 0,8 \\
& =0,32 \\
\mathrm{CFg} 3 & =\text { CFpasien } * \text { CFpakar } \\
& =0 * 0,4 \\
& =0
\end{aligned}
$$

Keterangan:

Pada Tabel 5, Pakar memberikan nilai masing-masing CFg..n = CF gejala ke- berapa atau urutan gejala gejala pada tiap penyakit. Untuk Nilai CF User CFpasien = Nilai CF dari pasien atau User terhadap diberikan berdasarkan gejala-gejala yang dirasakan gejala penyakit

oleh User. Adapun Nilai Bobot CF User dapat dilihat CFpakar = Nilai CF dari Pakar terhadap gejala pada Tabel 6 sebagai berikut:

penyakit

Berdasarkan langkah diatas, didapati tiga gejala penyakit rule 1 yang dicocokkan dengan gejala pasien. Langkah selanjutnya yaitu dengan menggunakan persamaan rumus $\mathrm{CF}$ kombinasi (Combine) sebagai berikut:

CFkombinasi1 $(\mathrm{CFg} 1, \mathrm{CFg} 2)=\mathrm{CFg} 1+\mathrm{CFg} 2 *(1-\mathrm{CFg} 1)$ $=0,64+0,32 *(1-0,64)$ 


$$
\begin{aligned}
& =0,64+0,32 *(0,36) \\
& =0,64+0,1152
\end{aligned}
$$

CFold $1=0,7552$

CFkomb.2(CFold1,CFg3)=CFold $1+\mathrm{CFg} 3 *(1-\mathrm{CFold} 1)$

$$
\begin{aligned}
& =0,7552+0 *(1-0,7552) \\
& =0,7552+0 *(0,2448) \\
& =0,7552+0
\end{aligned}
$$

CFrule $1=0,7552$

Keterangan:

CFkombinasi..n $(\mathrm{CFg} 1, \quad \mathrm{CFg} 2)=\mathrm{CF}$ kombinasi keberapa atau urutan kombinasi

$\mathrm{CFg} 1$ = CF gejala ke-1

$\mathrm{CFg} 2=\mathrm{CF}$ gejala ke-2

$\mathrm{CFg} 3=\mathrm{CF}$ gejala ke-3

CFold1 = Hasil dari perhitungan CFkombinasi 1

CFrule1`= Hasil akhir dari perhitungan CFkombinasi

Pada persamaan rumus CF kombinasi didapatkan hasil rule 1 yaitu 0,7552 , hasil tersebut kemudian di konversikan ke dalam bentuk persentase (\%) sehingga rule 1 akan dikalikan $100 \%$.

Persentase rule $1=$ CFrule $1 * 100 \%$

$$
=0,7552 * 100=75,52 \%
$$

Hasil persentase Pasien 1 yang di dapatkan dari rule 1 yaitu 0,7552, dimana saat hasil tersebut dibulatkan dengan mengambil dua angka dibelakang koma (,) menjadi $76 \%$ dengan rule untuk penyakit Otitis Externa Sirkumskripta. Proses perhitungan Pasien 1 akan dilanjutkan ke rule 2 untuk mengetahui hasil dari masing-masing rule sehingga dapat melihat perbandingan persentase rule.

\section{Hasil Perhitungan}

Adapun hasil perhitungan terhadap Pasien 1 dapat dilihat pada Tabel 7 sebagai berikut:

Tabel 7 Hasil Perhitungan Manual Nilai CF terhadap Pasien 1

\begin{tabular}{|c|c|c|c|}
\hline $\begin{array}{c}\text { Rule } \\
\text { ke }\end{array}$ & $\begin{array}{c}\text { Kode } \\
\text { Penyakit }\end{array}$ & Hasil Nilai CF & $\begin{array}{c}\text { Persentase } \\
(\%)\end{array}$ \\
\hline 1. & JP01 & 0,7552 & $76 \%$ \\
\hline 2. & JP02 & 0,32 & $32 \%$ \\
\hline 3. & JP03 & 0,48 & $48 \%$ \\
\hline 4. & JP04 & 0,8335 & $83 \%$ \\
\hline 5. & JP05 & 0,8586 & $86 \%$ \\
\hline 6. & JP06 & 0,32 & $32 \%$ \\
\hline 7. & JP07 & 0,24 & $24 \%$ \\
\hline 8. & JP08 & 0,16 & $16 \%$ \\
\hline 9. & JP09 & 0,32 & $32 \%$ \\
\hline 10. & JP10 & 0 & $0 \%$ \\
\hline
\end{tabular}

Hasil proses perhitungan menyeluruh masing-masing rule terhadap Pasien 1 mendapatkan hasil dengan mengambil nilai paling besar yaitu pada rule ke 5 dengan nilai CF 0,8586 dan persentase $86 \%$. Kesimpulan untuk mengukur tingkat akurasi dalam mengidentifikasi penyakit telinga pada Pasien 1 adalah sebesar $86 \%$, dimana Pasien 1 mengalami penyakit Otitis Media Akut.

\subsubsection{Perancangan Sistem}

Perancangan sistem merupakan konsep serta gambaran yang ditujukan dalam pembuatan aplikasi Sistem Pakar sebagai media antarmuka antara user dengan sistem. Perancangan sistem meliputi desain output, desain input, dan database.

\subsubsection{Desain Output}

Desain output merupakan hasil keluaran dari konsultasi yang dilakukan, dimana hasil tersebut berupa data pasien selaku user dan hasil tingkat akurasi dalam mengidentifikasi penyakit telinga.

\subsubsection{Desain Input}

Desain input merupakan rancangan dalam pengisian data pada sistem yang disajikan dalam bentuk form. Desain input juga akan menjadi antar muka terhadap pengguna dalam pelayanan konsultasi.

HALAMAN REGISTRASI

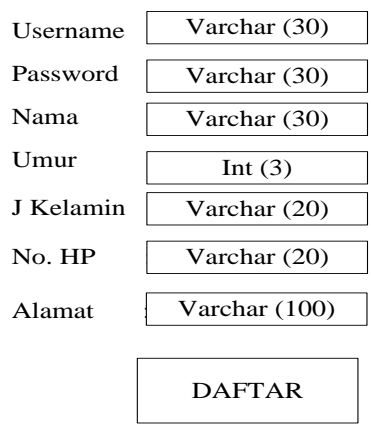

Gambar 5 Desain Input Form Registrasi

\subsubsection{Desain Database}

Pada penelitian ini, perancangan Aplikasi Sistem Pakar menggunakan database MySQL. Dalam database nantinya akan terdapat satu buah database (dbp_telinga) dan diikuti beberapa tabel didalamnya guna mengolah data dan menyimpan data Pakar. Salah satu tabel yang merupakan bagian dari database adalah sebagai berikut:

Tabel 8 Desain Tabel Penyakit

Nama database $\quad:$ dbp_telinga

Nama tabel : tb_penyakit 


Field key
\begin{tabular}{|l|l|l|c|l|}
\hline No & \multicolumn{1}{|c|}{ Name } & \multicolumn{1}{|c|}{ Type } & Size & \multicolumn{1}{|c|}{ Decsription } \\
\hline 1. & id_penyakit & Int & 11 & ID Penyakit \\
\hline 2. & kd_penyakit & Varchar & 10 & Kode Penyakit \\
\hline 3. & nm_penyakit & Varchar & 30 & Nama Penyakit \\
\hline 4. & Keterangan & Varchar & 250 & Keterangan \\
\hline
\end{tabular}

Hasil dari rancangan Aplikasi Sistem Pakar dapat dilihat menggunakan komputer melalui web browser. Untuk melakukan konsultasi pengguna diharuskan mendaftar terlebih dahulu guna memiliki akun untuk hak akses yang dimiliki pengguna. Adapun tampilan pendaftaran dari sistem dapat dilihat pada Gambar 5 sebagai berikut:

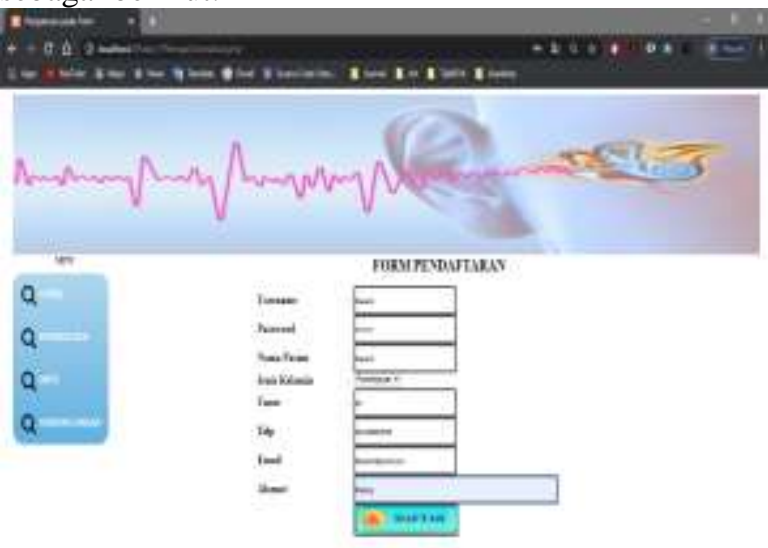

Gambar 5 Form Pendaftaran

Setelah mendaftar, maka dilanjutkan dengan login dan masukkan username dan password yang dimiliki. Selanjutnya pengguna dapat melakukan Konsultasi mengenai penyakit Telinga. Adapun tampilan konsultasi dapat dilihat seperti pada Gambar 6 sebagai berikut:

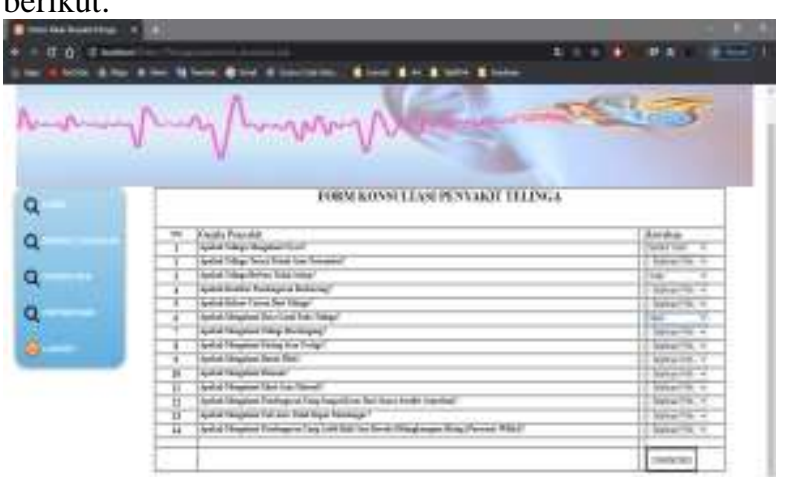

Gambar 6 Form Konsultasi

Apabila sudah menginputkan gejala yang dialami, dilanjutkan dengan menekan tombol diagnosa sehingga menampilkan form hasil konsultasi. Adapun tampilan dari form konsultasi dapat dilihat pada Gambar 7 sebagai berikut:

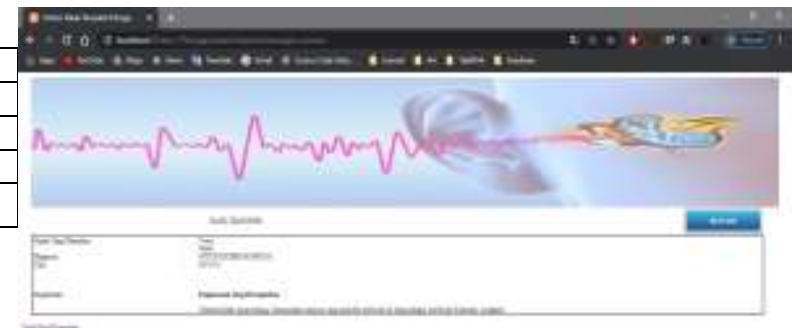

Gambar 7 Form Hasil Konsultasi

Untuk keakuratan Aplikasi Sistem Pakar digunakan perbandingan hasil, tingkat akurasi dihitung dengan rumus seperti berikut:

Tingkat Akurasi = jumlah data valid/total data $\times 100 \%$

Sehingga jika dihitung maka diperoleh hasil tingkat keakurat sistem pakar ini sebagai berikut:

Tingkat Akurasi $=8 / 10 \times 100 \%$

Dengan penerapan metode Forward Chaining dan Certainty Factor dalam sistem pakar identifikasi penyakit telinga terhadap 10 data uji diperoleh tingkat akurasi sebesar $80 \%$.

\section{Kesimpulan}

Berdasarkan penelitian yang dilakuakan dan telah diuraikan pada BAB sebelumnya maka diperoleh kesimpulan terhadap penelitian. Adapun kesimpulan yang diperoleh adalah sebagai berikut:

1. Implementasi metode Forward Chaining dan Certainty Factor untuk Aplikasi Sistem Pakar identifikasi penyakit telinga dapat membantu mengukur tingkat akurasi penyakit yang dialami pasien berdasarkan gejala-gejala yang dirasakan. Aplikasi Sistem Pakar identifikasi penyakit telinga memiliki tingkat akurasi sebesar $80 \%$.

2. Aplikasi Sistem Pakar yang bersifat friendly memberikan dampak penggunaan yang baik karena dapat memberi kemudahan kepada user dalam mengidentifikasi penyakit telinga yang dirasakan berdasarkan gejala-gejala yang dialami oleh pasien

3. Sistem Pakar identifikasi penyakit telinga ini dapat memberikan informasi yang berkaitan dengan penyakit telinga serta solusi dari penyakit tersebut. 


\section{Daftar Rujukan}

[1] Kurnia, D. (2018). Identifikasi Obesitas Pada Balita Di Posyandu Berbasis Artificial Intelligence. Jurnal Sains Dan Informatika, 4(1), 76-86. doi: 10.22216/jsi.v4i1.3370

[2] Imron, I., Afidah, M. N., Nurhayati, M. S., Sulistiyah, S., \& Fatmawati, F. (2019). Sistem Pakar Diagnosa Kerusakan Mesin Sepeda Motor Transmission Automatic dengan Metode Forward Chaining Studi Kasus: AHASS 00955 Mitra Perdana. Jurnal Ilmiah Universitas Batanghari Jambi, 19(3), 544. doi: 10.33087/jiubj.v19i3.742

[3] Sugiharni, G. A. D., \& Divayana, D. G. H. (2017). Pemanfaatan Metode Forward Chaining Dalam Pengembangan Sistem Pakar Pendiagnosa Kerusakan Televisi Berwarna. Jurnal Nasional Pendidikan Teknik Informatika (JANAPATI), 6(1), 20. doi: 10.23887/janapati.v6i1.9926

[4] Lestari, Y., Mesran, Suginam, \& Fadlina. (2017). Sistem Pakar Untuk Mendiagnosis Penyakit Tumor Otak Menggunakan Metode Certainty Factor ( CF ). Infotek, 2(1), 82-86. Retrieved fromhttps://ejurnal.amikstiekomsu.ac.id/index.php/infotek /article/ view/98

[5] Viviliani, V., \& Tanone, R. (2019). Perancangan Sistem Pakar Diagnosis Penyakit pada Bayi dengan Metode Forward Chaining Berbasis Android. Jurnal Teknik Informatika Dan Sistem Informasi, 5(1), 1-13. doi: 10.28932/jutisi.v5i1.1577

[6] Tuslaela., \& Permadi, D. (2018). SISTEM PAKAR DIAGNOSA PENYAKIT GIGI DAN MULUT BERBASIS WEB DENGAN METODE FORWARD CHAINING Tuslaela1,. Jurnal PROSISKO, 5(1). Retrieved from https://ejurnal.lppmunsera.org/index.php/PROSISKO/article/view/586/61 5

[7] Widyaningsih, M. (2018). Sistem Diagnosa Penyakit THT Pada Balita Menggunakan Dempster Shafer. JIKO (Jurnal Informatika Dan Komputer), 3(1), 27. doi: 10.26798/jiko.2018.v3i1.89

[8] Wang, J., Sung, V., Carew, P., Burt, R. A., Liu, M., Wang, Y., ... Wake, M. (2019). Prevalence of Childhood Hearing Loss and Secular Trends: A Systematic Review and Meta-Analysis. Academic Pediatrics, 19(5), 504-514. doi: 10.1016/j.acap.2019.01.010

[9] Alnuman, N., \& Ghnimat, T. (2019). Awareness of NoiseInduced Hearing Loss and Use of Hearing Protection among Young Adults in Jordan. International Journal of Environmental Research and Public Health, 16(16), 2961. doi: 10.3390/ijerph16162961

[10] Abdel Tawab, H. M., \& Tabook, S. M. S. (2019). Correlation Between Adenoid Hypertrophy, Tympanometry Findings, and Viscosity of Middle Ear Fluid in Chronic Otitis Media With Effusion, Southern Oman. Ear, Nose \& Throat Journal, 014556131987543. doi: 10.1177/0145561319875438

[11]Lou, Q., Zhu, H., \& Luo, Y. (2018). The Effects of Age at Cleft Palate Repair on Middle Ear Function and Hearing Level. (22), 1-5. doi: 10.1177/1055665618754632

[12] Yanto, B. F., Werdiningsih, I., \& Purwanti, E. (2017). Aplikasi Sistem Pakar Diagnosa Penyakit Pada Anak Bawah Lima Tahun Menggunakan Metode Forward Chaining. Journal of Information Systems Engineering and Business Intelligence, 3(1), 61. doi: 10.20473/jisebi.3.1.61-67

[13] Agus, B., Atiqah, H., \& Rizal, E. (2019). SISTEM PAKAR UNTUK MENENTUKAN SANKSI PELANGGAR LALU LINTAS SEPEDA MOTOR DAN MOBIL MENGGUNAKAN METODE FORWARD CHAINING BERBASIS WEB. Seminar Nasional Teknoka, 4(2502-8782), 15-19. doi: 10.22236/teknoka.v\%vi\%i.4272.

[14]Putra, H. W., Yuhandri., \& Nurcahyo, gunadi widi. (2019). Sistem Pakar Diagnosis Penyakit Ginjal Dengan Metoda Forward Chaining. Jurnal Sains Dan Informatika, 5(1), 7. doi: 10.22216/jsi.v5i1.4081

[15]Priyandari, Y., Zakaria, R., \& Syakura, A. (2017). Sistem Pakar Pemupukan Kelapa Sawit Menggunakan Metode Forward Chaining. PERFORMA : Media Ilmiah Teknik Industri, 16(2), 98-106. doi: 10.20961/performa.16.2.16978
[16]Arlis, S. (2017). Diagnosis Penyakit Radang Sendi Dengan Metode Certainty Factor. SATIN - Sains Dan Teknologi Informasi, 3(1), 42. doi: 10.33372/stn.v3i1.215

[17] Sumantoro, I., Arisandi, D., Siahaan, A., \& Mesran. (2017). Expert System of Catfish Disease Determinants Using Certainty Factor Method. International Journal of Recent Trends in Engineering and Research, 3(8), 202-209. doi: 10.23883/IJRTER.2017.3405.TCYZ2

[18]Riadi, A. (2017). PENERAPAN METODE CERTAINTY FACTOR UNTUK SISTEM PAKAR DIAGNOSA PENYAKIT DIABETES MELITUS PADA RSUD BUMI PANUA KABUPATEN POHUWATO. ILKOM Jurnal Ilmiah, 9(3), 309316. doi: 10.33096/ilkom.v9i3.162.309-316

[19] Suryadi, S., \& Murdani, M. (2019). PENERAPAN METODE CERTAINTY FACTOR DALAM PENGAMBILAN KEPUTUSAN DIAGNOSA KERUSAKAN SEPEDA MOTOR. JURNAL INFORMATIKA, 5(3), 22-25. doi: 10.36987/informatika.v5i3.732

[20] Setyaputri, K. E., Fadlil, A., \& Sunardi, S. (2018). Analisis Metode Certainty Factor pada Sistem Pakar Diagnosa Penyakit THT. Jurnal Teknik Elektro, 10(1), 30-35. doi: 10.15294/jte.v10i1.14031

[21] Girsang, R. R., \& Fahmi, H. (2019). Sistem Pakar Mendiagnosa Penyakit Mata KatarakDengan Metode Certainty Factor Berbasis Web. MATICS, 11(1), 27. doi: 10.18860/mat.v11i1.7673

[22] Hasibuan, N. A., Sunandar, H., Alas, S., \& Suginam, S. (2017). Sistem Pakar Mendiagnosa Penyakit Kaki Gajah Menggunakan Metode Certainty Factor. Jurasik (Jurnal Riset Sistem Informasi Dan Teknik Informatika), 2(1), 29. doi: 10.30645/jurasik.v2i1.16

[23]Army, W., Yuhandri., \& Sumijan. (2018). SISTEM PAKAR DIAGNOSIS PENYAKIT MENULAR DENGAN METODE FORWARD CHAINING DAN CERTAINTY FACTOR. Jurnal Sains Dan Informatika, 4(2), 171. doi: 10.22216/jsi.v4i2.3684

[24]Susilo, H. (2018). SISTEM PAKAR METODE FORWARD CHAINING DAN CERTAINTY FACTOR UNTUK MENGIDENTIFIKASI PENYAKIT PERTUSIS PADA ANAK. Rang Teknik Journal, 1(2), 185-194. doi: 10.31869/rtj.v1i2.764

[25] Yuwono, D. T., Fadlil, A., \& Sunardi, S. (2017). PENERAPAN METODE FORWARD CHAINING DAN CERTAINTY FACTOR PADA SISTEM PAKAR DIAGNOSA HAMA ANGGREK COELOGYNE PANDURATA. KLIK KUMPULAN JURNAL ILMU KOMPUTER, 4(2), 136. doi: 10.20527/klik.v4i2.89

[26] Prambudi, D. A., Edi Widodo, C., \& Puji Widodo, A. (2018). Expert System Application of Forward Chaining and Certainty Factors Method for The Decision of Contraception Tools. E3S Web of Conferences, 31, $10009 . \quad$ doi: 10.1051/e3sconf/20183110009

[27] Imamah, I., \& Siddiqi, A. (2019). Penerapan Teorema Bayes untuk Mendiagnosa Penyakit Telinga Hidung Tenggorokan (THT). MATRIK : Jurnal Manajemen, Teknik Informatika Dan Rekayasa Komputer, 18(2), 268-275. doi: 10.30812/matrik.v18i2.398

[28] Helmi A. Balfas (penulis); Joko Suyono, Y. (editor). (2018). Pengobatan penyakit telinga dan jaringan lunak di sekitarnya / Prof. Dr. dr. Helmi A. Balfas, Sp. THT(K), MARS ; editor, dr. Y. Joko Suyono. (C) 2018; Jakarta :: Penerbit buku kedokteran EGC,.

[29]Zulfian Azmi 1973- (penulis); Verdi Yasin 1977- (penulis). (2017). Pengantar sistem pakar dan metode : Introduction of expert system and method / penulis, Zulfian Azmi, S.T., M.Kom., Verdi Yasin, S.Kom., M.Kom.. Jakarta :; (c) 2017: Mitra Wacana Media,

[30] S. Sularno and P. Anggraini, "PENERAPAN ALGORITMA C4.5 UNTUK KLASIFIKASI TINGKAT KEGANASAN HAMA PADA TANAMAN PADI (Studi Kasus : Dinas Pertanian Kabupaten Kerinci)," J. Sains dan Inform., vol. 3, no. 2, p. 161, Nov. 2017 